\title{
Characterization of strains of Vibrio splendidus and $V$. tapetis isolated from corkwing wrasse Symphodus melops suffering vibriosis
}

\author{
Sigmund Jensen ${ }^{1}$, Ole B. Samuelsen ${ }^{1}$, Kari Andersen ${ }^{1}$, Lise Torkildsen ${ }^{1}$, \\ Christophe Lambert ${ }^{2}$, Gwénaëlle Choquet ${ }^{2}$, Christine Paillard ${ }^{2}$, Øivind Bergh ${ }^{1, *}$ \\ ${ }^{1}$ Department of Aquaculture, Institute of Marine Research, PO Box 1870 Nordnes, 5817 Bergen, Norway \\ ${ }^{2}$ Laboratoire des Sciences de l'Environnement Marin (LEMAR), Institut Universitaire Européen de la Mer (IUEM), \\ Université de Bretagne Occidentale (UBO), Place Copernic technopole Brest-Iroise, 29280 Plouzané, France
}

\begin{abstract}
Two vibrio bacteria pathogenic to the corkwing wrasse Symphodus melops were isolated. Vibriosis-inducing strain LP1 was isolated as the dominanting bacterium in kidney samples of dead and moribund wrasse from a population suffering vibriosis and high daily mortality in 1998 on the Norwegian west coast. The other vibriosis-inducing strain, LP2, was isolated from wrasse captured the following year. Re-infection experiments have confirmed that these strains cause vibriosis in corkwing wrasse. Both strains were typical vibrios sharing the traits of fermentative Gram-negative curved rods with motility and a positive oxidase reaction. Detailed biochemical and genetic characterisation revealed a close affiliation to known species of the marine environment. The first isolate, LP1, is a form of the ubiquitous seawater organism Vibrio splendidus, while the second isolate, LP2, is closely related to $V$. tapetis (previously only known as the brown ring disease agent in clams). Identification of the new wrasse pathogens $V$. splendidus LP1 and $V$. tapetis LP2 is facilitated by break points observed in this study.
\end{abstract}

KEY WORDS: Vibrio $\cdot$ Wrasse $\cdot$ Vibriosis $\cdot$ Taxonomy $\cdot$ Phylogeny

Resale or republication not permitted without written consent of the publisher

\section{INTRODUCTION}

The use of captured wrasse as cleaner fish to reduce infestations of ectoparasitic sea lice, mainly Lepeophtheirus salmonis and Caligus elongatus, on farmed Atlantic salmon Salmo salar has been developed as a supplement to the use of chemicals (Bjordal 1991, Treasurer 1994, Tully et al. 1996). Wrasse use is an alternative and biological method of control that has environmental advantages over the traditional chemical treatment. However, the occurrence of pathogens in wrasse is a disadvantage in salmon farming, both in terms of mortality on the wrasse itself and in the possibility of infecting the salmon. Two of the wrasse species most used are the goldsinny Ctenolabrus rupestris and the corkwing Symphodus melops. Both typical (Hjeltnes et al. 1995) and atypical strains of Aeromonas salmonicida have been isolated from wrasse, the latter being responsible for occasionally high mortality in goldsinny wrasse (Collins et al. 1991, Treasurer \& Laidler 1994, Bricknell et al. 1996, Laidler et al. 1999). No other bacteria, except the recently isolated Vibrio strain LP1 (Samuelsen et al. 2000), have to our knowledge been reported in wrasse.

A previously unknown disease of corkwing wrasse was encountered by us in 1998 when holding a group of apparently healthy wild-caught fish in the laboratory with the intention to use them for pharmacokinetic experiments. Mortality however was significantly reduced upon treatment with an antibacterial agent compared to untreated wrasse, indicating a bacterial aetiology or ethiology (Samuelsen et al. 2000). These findings motivated further trials with corkwing wrasse in 1999. Again, mortality of wild-caught wrasse was 
experienced although held under favourable conditions in the laboratory. As with the first group, bacteriological examinations were carried out with the intention to find a causative agent. Cultivation of kidney samples of moribund and dead fish indicated bacterial aetiology. Isolation yelded 1 dominant strain from both groups. The strain LP1 isolated from the 1998 group was tentatively assigned to the genus Vibrio (Samuelsen et al. 2000). The strain dominating the samplings from 1999 was numbered LP2.

The purpose of the present study was to characterise strains LP1 and LP2 isolated from dead and moribund corkwing wrasse at the biochemical, serological and genetical level and to identify them to species level.

\section{MATERIALS AND METHODS}

Experimental fish. Corkwing wrasse Symphodus melops were captured by fish trap near Bergen (Norway) in the autumns of 1998 and 1999 by a local fisherman. This method allowed wild wrasse of $45 \pm 9 \mathrm{~g}$ to be swiftly collected for transport to the Institute of Marine Research where approximately 400 individuals were stocked in flow-through storage tanks $(1 \mathrm{~m}$ deep $\times$ $2.5 \mathrm{~m}$ i.d.) held at $13 \pm 0.5^{\circ} \mathrm{C}$. The storage tanks were provided with artificial seaweed and plastic tubes for shelter. The fish were fed krill to satiation every second day (1998 group) or every day (1999 group). After approximately $4 \mathrm{wk}$ in the tanks, a general loss of appetite was noticed and the fish started to die. From each group, kidney samples from 20 moribund and dead fish were examined for the presence of bacteria by cultivation.

Bacterial isolation and cultivation. Before necropsy, the wrasse were disinfected with $70 \%$ ethanol. Posterior kidney samples were inoculated directly into nutrient blood agar (Oxoid, Basingstoke, UK) supplemented with $5 \%$ sheep blood and $1.5 \% \mathrm{NaCl}$ and slabs containing $150 \mu \mathrm{g}$ of the vibriostatic agent O/129 were placed on the agar plates, which were incubated aerobically at $15^{\circ} \mathrm{C}$ for a maximum of $7 \mathrm{~d}_{i}$ colonies were re-streaked before pure cultures were obtained. Pure cultures were prepared in marine broth (Difco) and frozen at $-70^{\circ} \mathrm{C}$ in $20 \%$ glycerol. Growth preferences were determined using the marine broth, which was occasionally filtered to remove precipitates (Hansen \& Sørheim 1991). After incubation at $18^{\circ} \mathrm{C}$ in 96 well microtitre plates, salt optimum was read at $495 \mathrm{~nm}$ using a Titertek multiscan plus spectrophotometer (Labsystems, Finland). The optimum temperature was estimated using parallel batch cultures incubated for 4 to $6 \mathrm{~h}$ and read at $600 \mathrm{~nm}$ in a spectrophotometer (Hitachi U-1100). Survival of washed cells during Star- vation in $80 \%$ seawater $(27 \%$, $80: 20$ seawater and distilled water) was monitored to assess the presence of LP1 and LP2 post-outbreaks. In 2 separate trials, single flasks of $100 \mathrm{ml}$ or $50 \mathrm{ml}$ cell suspensions were left static on the laboratory bench for repetitive plating-out on triplicate marine agar (Difco) plates incubated on the bench at room temperature $\left(\sim 20^{\circ} \mathrm{C}\right)$. The LP1 and LP2 strains were experimentally compared with the reference strains Vibrio splendidus NCIMB1, V. splendidus I LMG19031T, and the $V$. tapetis $\mathrm{B}_{1090}{ }^{\mathrm{T}}$ / CECT4600 isolated in October 1990 from diseased manila clams in 'Landeda' (Finistère, France) by Paillard \& Maes (1990) and described later by Borrego et al. (1996). Strains LP1 and LP2 can be obtained from the National Collection of Industrial and Marine Bacteria (NCIMB, Aberdeen, UK), where they are deposited under Accession nos. V. splendidus LP1 NCIMB 13825 and $V$. tapetis LP2 NCIMB 13826.

Phenotypic characterization. Biochemical profiles were determined using commercial API kits (bioMérieux, Missouri, USA). Strains LP1, LP2 and reference strains Vibrio splendidus NCIMB1 and $V$. tapetis B1090 were suspended in $80 \%$ seawater (API 20 E) or in distilled water supplemented with $1.5 \% \mathrm{NaCl}$ (API $50 \mathrm{CH}$ ). The strips were incubated at $20^{\circ} \mathrm{C}$, and results were determined after $48 \mathrm{~h}$ of incubation as described by Wiik et al. (1995).

The minimum concentration of an antibacterial agent at which complete inhibition occurred (MIC) was determined using the agar dilution method (Washington 1985). Tests were performed as described by Samuelsen \& Lunestad (1996), in triplicate, with reference strains according to Torkildsen et al. (2000). The antibacterial agents tested were flumequine, oxolinic acid and oxytetracycline.

The nature of the antigens covering the surface of LP2 were addressed in an agglutination assay using polyclonal antibodies (Pasteur, France) raised in a rabbit against cells of Vibrio tapetis strain B1090. Prepared antibodies $(5 \mu \mathrm{l})$ were presented to LP2 on Teflon slides (Polyabo) allowing for a direct visualization of the agglutination. Prior to agglutination, LP2 had been cultured for $72 \mathrm{~h}$ and developed colonies on marine agar plates that were harvested in $0.5 \mathrm{ml}$ autoclaved seawater and spotted ( $5 \mu \mathrm{l})$ into the wells of the slide.

PCR amplification. 16S rDNA genes of whole cells were PCR-amplified from suspensions prepared as follows. Isolates were grown aerobically at $10^{\circ} \mathrm{C}$ in $10 \mathrm{ml}$ marine media shaken at $120 \mathrm{rpm}$ overnight (approx. $24 \mathrm{~h}) ; 1 \mathrm{ml}$ was harvested in an Eppendorf centrifuge at $13000 \mathrm{rpm}(15800 \times g)$ for $3 \mathrm{~min}$. The cell pellet was resuspended in $1 \mathrm{ml} 0.9 \% \mathrm{NaCl}$, centrifuged again, washed in $1 \mathrm{ml}$ of the $\mathrm{NaCl}$ and stored at $-80^{\circ} \mathrm{C}$ in $100 \mathrm{\mu l}$ autoclaved distilled water. 
PCR was performed in $50 \mu$ reaction mixtures in $0.5 \mathrm{ml}$ microfuge tubes using the universal bacterial primers 27f (AGAGTTTGATC(A:C)TGGCTCAG) and 1492r (TACGG(C:T)TACCTTGTTACGACTT) covering nearly full length 16S rDNA (Lane 1991). Reactions were performed with the reagents supplied with Promega Taq polymerase at a magnesium-ion concentration of $25 \mathrm{mM}$, with $1 \mathrm{\mu l}$ template, and $50 \mathrm{pmol}$ of each primer (27f and 1492r). Deoxynucleotide triphosphates were supplied at $200 \mu \mathrm{M}$ final concentrations. Reactions were carried out in a PCT-200 thermal cycler (MJ Research) with an initial denaturation step of $95^{\circ} \mathrm{C}$ for $5 \mathrm{~min}, 30$ cycles of $92^{\circ} \mathrm{C}$ for $1 \mathrm{~min}, 60^{\circ} \mathrm{C}$ for $1 \mathrm{~min}$ and $72^{\circ} \mathrm{C}$ for $45 \mathrm{~s}$, followed by a final extension of $5 \mathrm{~min}$ at $72^{\circ} \mathrm{C}$. A positive control was performed with Escherichia coli B sigma DNA. Reaction products were examined for size and purity on $1 \%$ agarose gels visualised by staining with ethidium bromide (Sambrook et al. 1989).

Sequence analysis. The amplified genes were cleaned using a pre-sequencing kit (Amersham Life Sciences) and subjected to cycle sequencing in the same PCR machine as mentioned above using a dye terminator kit (ABI Prism BigDye) and primers from Lane (1991). Completed reactions were precipitated according to the manufacturer's protocol and run on an ABI Prism Model 377 sequencer. Alignments were performed manually and adjusted to the secondary structure model of Escherichia Coli (M24996). Corrections necessary to meet the model were performed for LP1 and LP2 and in the reference sequences retrieved from the EMBL GenBank. Bases 17-1507 (LP1) and 8-1479 (LP2) were covered, omitting problematic positions found in both isolates at Positions 0-7, 81-100, 180-190, 445-490 and 1018-1027 (E. coli numbering). The LP1 and LP2 sequences have been deposited in GenBank and are available under Accession Nos. AY129277 and AY129278.

DNA extraction. Nucleic acids were extracted for hybridization and reversed-phase high-performance liquid chromatography (HPLC) by methods described in Marmur (1961) and Sambrook et al. (1989). For HPLC, log cultures were harvested and cells lysed by lysosyme and sodium dodecyl sulphate (SDS). Subsequent extraction by phenol and chloroform isoamylalcohol removed the cell material so that the nucleic acids could be precipitated in ethanol and sodium acetate. RNase removed the RNA and the organic extraction was repeated before the DNA was precipitated again and resuspended in water (Sambrook et al. 1989). DNA to be hybridised was extracted following the method of Marmur (1961), with slight adaptations comprising addition of sarkosyl and Proteinase $\mathrm{K}$ for lysis and using only ethanol for precipitation. This DNA was purified in a caesium chloride gradient under ultracentrifugation.
Relative GC content (sum of percentage of guarine and cytosine) of chromosomal DNA. DNA hydrolysis initiated the HPLC analysis and was performed as described in Tamaoka \& Komagata (1984) using Nuclease P1 and bacterial alkaline phosphatase (Sigma). Following the method of these authors, nucleosides of LP1, LP2 and reference Vibrio splendidus NCIMB1 were analysed for mol\% GC content using HPLC. In order to determine the molar absorption coefficient for each of the 4 nucleosides, a mixture of the compounds dissolved in distilled water at a concentration of $10 \mu \mathrm{g}$ $\mathrm{ml}^{-1}$ was analysed $(\mathrm{n}=5)$.

DNA-DNA hybridization. Chromosomal DNA of LP1 and LP2 was spotted single-stranded as $300 \mathrm{ng}$ replicates $(\mathrm{n}=4)$ on Hybond $\mathrm{N}$ membranes (Amersham) using a vacum bond dot-blot system (SRC96D Minifold I, Schleicher \& Schüll) before fixing to the surface by UV light (Sambrook et al. 1989). Chromosomal DNA of Vibrio tapetis B1090 was randomly labelled by fluoresceine-11-dUTP (Kit ECL, RPN 3040/3041) and that of $V$. splendidus I LMG19031 ${ }^{\mathrm{T}}$ with alkaline phosphatase using an alkphos direct labelling kit (Kit ECL, RPN 3680/3682). The membranes were soaked in buffer supplied by the kits and allowed to hybridise to the labelled probes for $20 \mathrm{~h}$ at $60^{\circ} \mathrm{C}$ (RPN 3040/3041) or $18 \mathrm{~h}$ at $55^{\circ} \mathrm{C}(\mathrm{RPN} 3680 / 3682)$ in a hybridization oven (Appligène Oncor, France). Unbound V. tapetis B1090 was washed off the membranes 3 times $\times 5 \mathrm{~min}$ at $60^{\circ} \mathrm{C}$ in $1 \times \mathrm{SSC}$ (trisodium citrate $15 \mathrm{mM}, \mathrm{NaCl} 0.15 \mathrm{mM}$ ), $0.1 \%(\mathrm{w} / \mathrm{v}) \mathrm{SDS}$ and finally in $0.5 \times \mathrm{SSC}, 0.1 \%(\mathrm{w} / \mathrm{v})$ SDS. Unbound $V$. splendidus I LMG19031 ${ }^{\mathrm{T}}$ were removed in 2 successive washes for $10 \mathrm{~min}$ at $55^{\circ} \mathrm{C}$ using the 2 buffers supplied by the kit (RPN 3680/3682). The membranes were subsequently blocked and soaked in a detection reagent. Hybridised DNA enhanced chemiluminescence through peroxidase-catalyzed oxidation of luminol (RPN 3040/3041 kit) or a alkaline phosphatase-catalysed reaction (RPN 3680/3682 kit). Emitted chemiluminescence was detected and quantified using a FLUOR-S ${ }^{\mathrm{TM}}$ multilmager system (BioRad). The data were analysed using a Multi-analyst software (BioRad) calibrated with homologous DNA from LMG19031 ${ }^{\mathrm{T}}$ and B1090 on the filters $(100 \%$ re-association rate) and herring sperm DNA (0\% re-association rate).

\section{RESULTS}

\section{Pathogenic observations of wrasse Symphodus melops}

In both groups (1989 and 1999) of wrasse, mortality did not plateau but continued until the remaining fish were anaesthetised and subsequently killed approxi- 
mately 4 wk after the first signs of infection. A general loss of appetite and reduced swimming was observed. In some fish, skin ulcerations occurred.

\section{Isolation and primary characteristics}

Colony morphology revealed LP1 and LP2 to be dominant in kidney samples of diseased wrasse. Smooth-edged, greyish-white colonies with zones of $\beta$-haemolysis on blood agar plates were typical of LP1. Colonies of LP2 looked similar, but displayed no haemolysis. Colony morphology of both strains stayed virtually constant during sub-cultivation on marine agar plates and plates left for $2 \mathrm{mo}$ at $18^{\circ} \mathrm{C}$ in the dark. Marine broth batches of LP2 kept their original yellowish colour, while LP1 darkened and turned brownish within 2 wk aerobically at room temperature. Both strains are likely to be found in ambient in situ seawater during post-outbreaks, as our experiment revealed almost every thousandth cell to be cultivable after 1 mo starvation (Fig. 1). Growth required salt, but not $\mathrm{O}_{2}$. Microscopic observations revealed a curved morphology. Both strains were motile and a slightly more slender cell type was noted for LP2 compared to LP1. They are typical heterotrophs that readily double every $1.5 \mathrm{~h}$ when shaken at $20^{\circ} \mathrm{C}$ in marine media. A phylogenetic relationship was found between LP1 and Vibrio splendidus and LP2 and V. tapetis; hence further characterization was focused on these species. Examination of the carbohydrate metabolism (API) revealed some interesting details of intra- and interspecific break-point substrates (see 'Discussion') and facilitated strain discrimination on the basis of sorbitol, sucrose and $\beta$-gentiobiose. Sorbitol was only metabolised by LP1, sucrose only by LP2 (Table 1) and

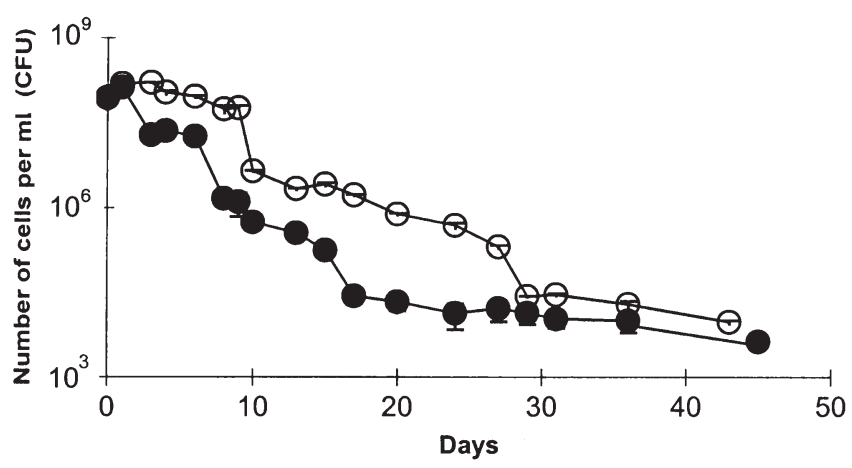

Fig. 1. Bacterial strains LP1 (O) and LP2 (•) survival during starvation in sea water at room temperature $\left(\sim 20^{\circ} \mathrm{C}\right)$ at an initial density of $8.7 \times 10^{7}$ and $8.5 \times 10^{7}$ cells $\mathrm{ml}^{-1}$, respectively. Colony-forming units were determined regularly on triplicate marine agar plates. Note logarithmic vertical axis. Error bars $= \pm \mathrm{SE}$
Table 1. Characteristics of vibrios pathogenic to wrasse Symphodus melops. \%GC: sum of percentage of guanine and cytosine $-=$ negative,$+=$ positive reaction

\begin{tabular}{|lcc|}
\hline Parameter & LP1 & LP2 \\
\hline Morphology & Curved rod & Curved rod \\
Size $(\mu \mathrm{m})$ & $0.7 \times 2.2$ & $0.6 \times 3.0$ \\
Gram stain & - & - \\
Cytochrome oxidase & + & + \\
NaCl optimum (w/v) & $30 \%$ & $25 \%$ \\
Temperature optimum & $28^{\circ} \mathrm{C}$ & $23^{\circ} \mathrm{C}$ \\
Growth at $37^{\circ} \mathrm{C}$ & + & - \\
Arginine dehydrogenase & + & - \\
Voges-Proskauer & - & - \\
$\beta$-gentiobiose & - & - \\
Glucose utilisation & + & + \\
Ribose utilisation & + & + \\
Sorbitol utilisation & + & - \\
Sucrose utilisation & - & + \\
Mannitol utilisation & + & - \\
DNA composition $(\% \mathrm{GC})$ & 45.9 & 43.8 \\
\hline
\end{tabular}

$\beta$-gentiobiose only by $V$. splendidus NCIMB1, while $V$. tapetis B1090 metabolised none of the three (data not shown).

\section{Antibiotic sensitivity (MIC)}

The bacterial strain LP1 had a minimum inhibitory concentration of $0.06 \mu \mathrm{g} \mathrm{ml}^{-1}$ for oxolinic acid, $0.13 \mu \mathrm{g}$ $\mathrm{ml}^{-1}$ for flumequine and $1.0 \mu \mathrm{g} \mathrm{ml}^{-1}$ for oxytetracycline. Corresponding values for LP2 were $0.25,0.5$ and $2 \mu \mathrm{g}$ $\mathrm{ml}^{-1}$ respectively. Both LP1 and LP2 were sensitive to the vibriostatic agent O/129.

\section{Antigens}

Strain LP2 was investigated for modified surface characteristics related to the Vibrio tapetis B1090 originally isolated from a clam (Paillard \& Maes 1990). A modification was found in LP2, as its agglutination by B1090 antibodies was reduced and moderate compared to the B1090 itself. The difference suggests altered surface characteristics in LP2. No agglutination of LP2 was observed by antibodies raised against $V$. cholerae.

\section{DNA-DNA hybridisation}

DNA-DNA homology of LP1 and LP2 and their closest phylotypes was clearly above the $70 \%$ species limit defined by Wayne et al. (1987). Re-association percentages for LP1 vs Vibrio splendidus I LMG19031T was 78.4\% (3.6\% SD) and for LP2 and V. tapetis B1090 76.8\% (4.5\% $\mathrm{SD})$. 


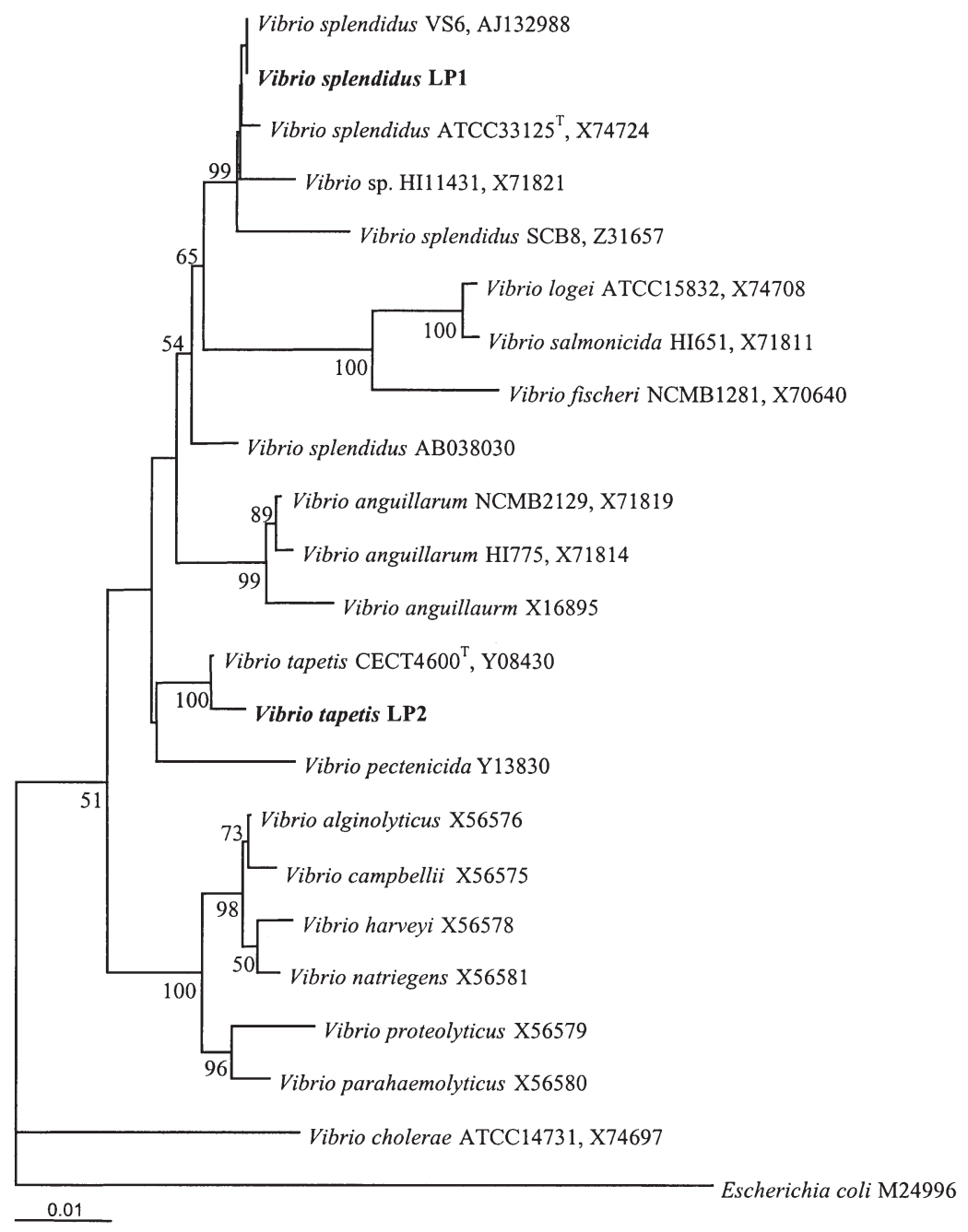

Fig. 2. Bacterial strains LP1 and LP2. Phylogenetic distance tree for LP1 and LP2 and representative members of the genus Vibrio. Scale bar: 1\% sequence divergence along horizontal lines connecting any 2 species; numbers at the nodes: bootstrap values ( $<50 \%$ not shown). Escherichia coli was used as an outgroup. Tree is constructed by programs in the PHYLIP Version 3.5 package (SEQBOOT, DNADIST, FITCH Kimura 2-parameter and CONSENSE: Felsenstein (1988)

porating 21 reference sequences positioned LP1 and LP2 in adjacent and recognizable clusters separate from the clusters of $V$. anguillarum and $V$. salmonicida (Wiik et al. 1995) and the 'vibrio core' organisms observed near $V$. harveyi (Dorsch et al. 1992). The pylogenetic positions of LP1 and LP2 are supported by the chromosomal GC mol\% given in Table 1 .

\section{DISCUSSION}

Bacteria found to cause vibriosis in the corkwing wrasse Symphodus melops were characterised by traditional and molecular methods, which led to the identification of 2 recognised species not previously associated with wrasse. Characterisation revealed break points facilitating recognition of the new wrasse pathogens Vibrio splendidus LP1 and V. tapetis LP2.

Phylogenetic evidence supports the conclusion that 1 representative of $\mathrm{Vib}$ rio splendidus and 1 representative of $V$. tapetis were isolated. Analysis based on the distance-tree method (Felsenstein 1988) showed robust $V$. splendidus and $V$. tapetis affiliation. A very high sequence homology with more than $99 \% 16$ S rDNA identity was found for both isolates. The LP1 clearly fell among strains characterised as $V$. splendidus. LP1 and V. splendidus grouped together in every bootstrap resampling performed of the distance tree presented. Local tree topology however was less clear, with many nearly identical sequences positioned at low bootstrap values. The $V$. splendidus group has been much studied, and 11

\section{Phylogeny}

Homology searches performed by Blast (Altschul et al. 1990) revealed the isolates to have a very high affiliation to previously described species of the marine environment. Blast identified LP1 as a Vibrio splendidus (X74724) and LP2 as a V. tapetis (Y08430) both sharing $>99 \%$ of the investigated $16 \mathrm{~S}$ rDNA. Unique nucleotide substitutions of LP1 were found at Positions $1355(\mathrm{G}), 1403(\mathrm{C})$ and $1437(\mathrm{G})$, and of LP2 at $1101(\mathrm{C})$, 1139 (G) and at 1141 (A) (Escherichia coli numbering). The construction of a phylogenetic tree (Fig. 2) incor- representatives were detected in GenBank, 4 of which were retrieved and incorporated in our tree. Other GenBank sequences found situated in the 'splendidus cluster' were Vibrio sp. Da2, Vibrio sp. EN280 and Vibrio sp. TK327, but for clarity these were omitted from further analysis. A relationship was also detected with $V$. aestuarianus, but this species was excluded because it was represented by 2 different sequences, one (AF172840) of which was closely related to LP1 while the other (X74689) unexpectedly was not. The phylogeny of LP2 was more clear-cut as this isolate related to a species defined by the $1 \mathrm{~V}$. tapetis (B1090) 
only. In the alignment of LP1 and LP2 ambiguous nucleotides were omitted for clarity. Inclusion of those nucleotides and the variable V3 region (Neefs et al. 1993) produced no new lineages for LP1 and LP2. In general, the phylogeny was supportive of the recognised vibrio groups represented by the species $V$. harveyi and $V$. anguillarum (Dorsch et al. 1992), $V$. salmonicida (Wiik et al. 1995), V. tapetis (Borrego et al. 1996) and V. splendidus. V. cholerae is a distant Vibrio and closer to the Escherichia coli used here as an outgroup.

Phylogenetic analysis suggested that 2 recognised vibrio species had been isolated. This was supported by the DNA-DNA hybridization that, for both isolates, was above the $70 \%$ species limit defined by Wayne et al. (1987). Using HPLC we found chromosomal mol\% GC values, as expected for LP1 and LP2 in the range of $V$. splendidus (45 to $46 \%$ ) and V. tapetis (43 to $46 \%$ ) respectively (Baumann et al. 1984, Borrego et al. 1996).

The isolates were also investigated by a set of physiological and biochemical characters for functional comparisons. From the API data it was noted that LP1 and LP2 were more metabolically diverse than their tested relatives. Mannitol and gluconate reflected phylogenetic distance, discriminating between relatives that were metabolising these substances (Vibrio splendidus NCIMB1/LP1) and those that were not $(V$. tapetis B1090/LP2). The enzyme reaction arginine dihydrolase distinguished these species likewise. LP1 differed from NCIMB1 in the metabolism of sorbitol, lactose and b-gentiobiose while LP2 differed from B1090 in the metabolism of ribose, lactose, melibiose and sucrose. Of these, $\beta$-gentiobiose was the only substrate not utilized by the new isolates. Interestingly, utilization of sucrose by LP2 contrasted with that of B1090 in a test used for the routine identification of $V$. tapetis (Maes \& Paillard 1992, Borrego et al. 1996). More importantly, metabolic break points were seen in the metabolism of sorbitol, sucrose and $\beta$-gentiobiose, which are solely used by LP1, LP2 and NCIMB1, and not by B1090. Hence, minor intra- and interspecific metabolic differences have been identified, adding functional support to the close genetic relationship found.

LP1 and LP2 are halophiles growing optimally around room temperature in the presence or absence of oxygen, and reach high turbidity whether cultured in shake-flasks or stationary test tubes. Slightly higher growth rates were noted for LP1, which were also slightly easier to cultivate from sea water. Within the first 2 to $4 \mathrm{~d}$ of starvation, the number of viable cells was similar to that reported by other investigators (e.g. Enger et al. 1990). In the absence of substrates, culturability was high, suggesting the presence of LP1 and LP2 cells in sea water post-outbreaks where viable cells may trigger vibriosis. The heterotrophic nature of the cells and their quick response in forming colonies upon transfer to nutrient-rich marine agar even after starvation for some weeks in sea water suggest that LP1 and LP2 have an opportunistic life style.

Physiologically, LP2 had surface characteristics not identical to those of B1090. Although phylogenetically very close, LP2 and B1090 were found in different hosts, suggesting the adaptation of antigenic surface characteristics to cope with their various environments (fish-clam). Changes in the expression of surface antigens may reflect changes in infectivity or virulence of the cells.

Vibrio spp. have now in addition to Aeromonas spp. been found in wrasse. LP1 belongs to a species previously known to be pathogenic to fishes (Gatesoupe et al. 1999). LP2, however, is a new fish pathogen. Until now, Vibrio tapetis has been found pathogenic only in the clam species Ruditapes philippinarum, $R$. decussatus, Tapes rhomboïdes and Venerupis aurea (Maes \& Paillard 1992). Vibrio tapetis was first isolated in 1990 in Landéda (Finistère, France) by Paillard \& Maes (1990). V. tapetis colonised the periostracum and induced typical disease signs in clams, i. e. an abnormal brown ring of melanized organic shell matrix on the inner of the shell, so so-called 'brown ring disease' (BRD) (Paillard et al. 1989, 1994, Paillard \& Maes 1995a,b). With the development of the disease, this vibrio is able to invade internal tissues resulting in death (Allam et al. 2002). In other adult bivalves such as the oysters Crassostrea gigas, $C$. virginica, cockles, or Pecten maximus, no BRD reproduction was observed after $V$. tapetis challenge (Maes \& Paillard 1992, Paillard et al. 1996). The present paper is the first study to demonstrate that $V$. tapetis can be isolated from a diseased marine vertebrate. LP2 was not pathogenic for salmon or goldsinny wrasse, but was found pathogenic in corkwing wrasse (Ø.B. \& O.B.S. unpubl. data). Further investigations testing its pathogenicity on clams and also on other fishes cultivated with wrasse should be performed to determine the pathogenicity and host range of this new strain of $V$. tapetis. Its geographical distribution has also to be determined: $V$. tapetis has been detected mainly from Scotland to Spain (Cadiz) and although BRD is known as a cold-water disease, it has never been isolated in Norway.

The wrasse-pathogenic Vibrio bacteria described herein can be identified by 3 unique substitutions in their 16S rRNA genes and the metabolism of sorbitol (V. splendidus LP1) and sucrose (V. tapetis LP2).

Acknowledgements. This work was funded by the Norwegian Research Council (Project 121799/112). 


\section{LITERATURE CITED}

Allam B, Paillard C, Ford SE (2002) Pathogenicity of Vibrio tapetis, the etiologic agent of brown ring disease in clams. Dis Aquat Org 48:221-231

Altschul SF, Gish W, Miller W, Myers EW, Lipman DJ (1990) Basic local alignment search tool. J Mol Biol 215:403-410

Baumann P, Furniss AL, Lee JV (1984) Facultatively anaerobic gram-negative rods In: Murray RGE, Brenner DJ, Bryant MP, Holt JG, Krieg NR and 5 others (eds) Bergey's manual of systematic bacteriology, Vol I. Williams \& Wilkins, London, p 516-545

Bjordal $\AA$ (1991) Wrasse as cleaner-fish for farmed salmon 1991. Progr Underwat Sci 16:17-28

Borrego JJ, Castro D, Luque A, Paillard C, Maes P, Garcia MT, Ventosa A (1996) Vibrio tapetis sp. nov., the causative agent of the brown ring disease affecting cultured clams. Int J Syst Bacteriol 46:480-484

Bricknell IR, Bruno DW, Stone J (1996) Aeromonas salmonicida infectivity studies in goldsinny wrasse, Ctenolabrus rupestis (L). J Fish Dis 19:469-474

Collins RO, Ferguson DA, Bonniwell MA (1991) Furunculosis in wrasse. Vet Rec 12

Dorsch M, Lane D, Stackebrandt E (1992) Towards a phylogeny of the genus Vibrio based on 16S rRNA sequences. Int J Syst Bacteriol 42:58-63

Enger Ø, Hoff KA, Schei GH, Dundas I (1990) Starvation survival of the fish pathogenic bacteria Vibrio anguillarum and Vibrio salmonicida in marine environments. FEMS Microbiol Ecol 74:215-220

Felsenstein J (1988) Phylogenies from molecular sequences: inference and reliability. Annu Rev Genet 22:521-565

Gatesoupe FJ, Lambert C, Nicolas JL (1999) Pathogenicity of Vibrio splendidus strains associated with turbot larvae, Scophthalmus maximus. J Appl Microbiol 87:757-763

Hansen HG, Sørheim R (1991) Improved method for phenotypical characterization of marine bacteria. J Microbiol Methods 13:231-241

Hjeltnes B, Bergh Ø, Wergeland H, Holm JC (1995) Susceptibility of Atlantic cod Gadu morhua, halibut Hippoglossus hippoglossus and wrasse (Labridae) to Aeromonas salmonicida subsp. salmonicida and the possibility of transmission of furunculosis from farmed salmon Salmo salar to marine fish. Dis Aquat Org 23:25-31

Laidler LA, Treasure JW, Grant AN, Cox DI (1999) Atypical Aeromonas salmonicida infection in wrasse (Labridae) used as cleaner fish of farmed Atlantic salmon, Salmo salar L, in Scotland. J Fish Dis 22:209-213

Lane DJ (1991) 16S/23S rRNA sequencing. In: Stackebrandt E, Goodfellow M (eds) Nucleic acid techniques in bacterial systematics. John Wiley \& Sons, Chichester, p 177-203

Maes P, Paillard C (1992) Effet de Vibrio P1, pathogène de Ruditapes philippinarum sur d'autres espèces de bivalves. Haliotis 14:141-148

Marmur J (1961) A procedure for the isolation of deoxyribonucleic acid from micro-organisms. J Mol Biol 3: 208-218

Neefs JM, Peer YV, Rijk P, Chapelle S, Wachter R (1993) Compilation of small ribosomal subunit RNA structures. Nucleic Acids Res 21:3025-3049

Paillard C, Maes P (1990) Etiologie de la maladie de l'anneau brun chez Tapes philippinarum: pathogénicité d'un Vibrio

Editorial responsibility: David Bruno,

Aberdeen, Scotland, UK sp. CR Acad Sci Sér III Sci Vie 310:15-20

Paillard C, Maes P (1995a) The brown ring disease in the Manila clam, Ruditapes philippinarum. 1. Ultrastructural alterations of the periostracal lamina. J Invertebr Pathol 65:91-100

Paillard C, Maes P (1995b) The brown ring disease in the Manila clam, Ruditapes philippinarum. 2. Microscopic study of the brown ring syndrome. J Invertebr Pathol 65: 101-110

Paillard C, Percelay L, Le Pennec M, Le Picard D (1989) Origine pathogène de 'l'anneau brun' chez Tapes philippinarum (Mollusque, bivalve). CR Acad Sci Sér III Sci Vie 309:235-241

Paillard C, Maes P, Oubella R (1994) Brown ring disease in clams. Annu Rev Fish Dis 4:219-240

Paillard C, Alcox K, Ford SE (1996) Changes in hemolymph and extrapallial fluid parameters in the american oyster, Crassostrea virginica affected by the juvenile oyster disease. Aquat Living Resour 9:145-158

Sambrook J, Fritsch EF, Maniatis T (1989) Molecular cloning: a laboratory manual, 2nd edn. Cold Spring Harbor Laboratory Press, New York

Samuelsen OB, Lunestad BT (1996) Bath treatment, an alternative method for the administration of the quinolones flumequine and oxolinic acid to halibut Hippoglossus hippoglossus, and in vitro antibacterial activity of the drugs against some Vibrio sp. Dis Aquat Org 27:13-18

Samuelsen OB, Húsgard S, Torkildsen L, Bergh Ø (2000) The efficacy of a single intraperitoneal injection of flumequine in the treatment of systemic vibriosis in corkwing wrasse Symphodus melops. J Aquat Anim Health 12:324-328

Tamaoka J, Komagata K (1984) Determination of DNA base composition by reversed-phase high-performance liquid chromatography. FEMS Microbiol Lett 25:125-128

Torkildsen L, Samuelsen OB, Lunestad BT, Bergh O (2000) Minimum inhibitory concentrations of chloramphenicol, florfenicol, trimethoprim/sulfadiazine and flumequine in seawater of bacteria associated with scallops (Pecten maximus) larvae. Aquaculture 185:1-12

Treasurer JW (1994) Prey selection and daily food consumption by a cleaner fish, Ctenolabrus rupestis (L), on farmed Atlantic salmon, Salmo salar. Aquaculture 122:269-277

Treasurer JW, Laidler LA (1994) Aeromonas salmonicida infection in wrasse (Labridae) used as cleaner fish, on an Atlantic salmon, Salmo salar L., farm. J Fish Dis 17: 155-161

Tully O, Daly P, Lysaght S, Deady S, Varian SJA (1996) Use of cleaner-wrasse (Centrolabrus exoletus [L] and Ctenolabrus rupestis [L]) to control infestations of Caligus elongatus Nordmann on farmed Atlantic salmon. Aquaculture 142:11-24

Washington JA II (1985) Susceptibility tests: agar dilution. In: Lennette EH, Balows A, Hausler WJ Jr, Shadomy HJ (eds) Manual of clinical microbiology, 4th edn. American Society for Microbiology, Washington, DC, p 967-971

Wayne LG, Brenner DJ, Colwell RR, Grimont PAD and 7 others (1987) Report of the ad hoc committee on reconciliation of approaches to bacterial systematic. Int J Syst Bacteriol 37:463-464

Wiik R, Stackebrandt E, Valle O, Daae FL, Rødseth OM, Andersen K (1995) Classification of fish-pathogeneic vibrios based on comparative 16S rRNA analysis. Int J Syst Bacteriol 45:421-428

Submitted: March 22, 2002; Accepted: July 26, 2002

Proofs received from author(s): December 12, 2002 